\begin{tabular}{|c|c|c|}
\hline 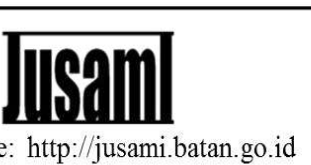 & Jurnal Sains Materi Indonesia & $\begin{array}{l}\text { Akreditasi LIPI } \\
\text { No.. } 602 / \text { AUU/P2MI-LIPI/03/2015 } \\
\text { Tanggal 15 April 2015 } \\
\text { ISSN : 1411-1098 }\end{array}$ \\
\hline
\end{tabular}

\title{
THE EFFECT OF PRETREATMENT OF MICROWAVE HEATING ON EFFICIENCY OF HYDROLYSIS TIME AND á- CELLULOSIC CHARACTERISTICS OF PALM OIL WASTE BIOMASS
}

\author{
Fitriani Kasim, Khaswar Syamsu' ${ }^{2}$, Dwi Setyaningsih ${ }^{2}$, \\ Prayoga Suryadarma ${ }^{2}$ and Sudirman ${ }^{3}$ \\ ${ }^{1}$ Department of Agricultural Product Technology - Andalas University \\ Jl. Limau Manis Padang, 25163 \\ ${ }^{2}$ Department of Agricultural Industrial Technology - Bogor Agricultural University \\ Dramaga, Bogor, 16680 \\ ${ }^{3}$ Center for Science and Technology of Advanced Material (PSTBM) - BATAN \\ Kawasan Puspiptek, Serpong 15314, Tangerang Selatan \\ E-mail : fitri123mabit@gmail.com
}

Received: 27 July 2018

Revised: 13 September 2018

Accepted: 27 September 2018

\begin{abstract}
THE EFFECT OF PRETREATMENT OF MICROWAVE HEATING ON EFFICIENCY OF HYDROLYSIS TIME AND $\alpha$-CELLULOSIC CHARACTERISTICS OF PALM OIL WASTE BIOMASS. This research is underlied by the needs of various industries for alpha cellulose, especially for the needs of raw material for cellulose nanocristalline, from fiber derived from the most potential waste biomass in Indonesia, namely oil palm empty fruit bunches (OPEFB) and mesocarp fibers. This study aims to find out the effect of pretreatment by microwave heating on the efficiency of hydrolysis time and alpha cellulose characteristics from palm oil waste biomass. To produce alpha cellulose, acid hydrolysis is commonly used with the multistage pulping process method, where the fiber is dissolved into $\mathrm{HNO}_{3}$ mixed acid, $3.5 \%$ and $\mathrm{NaNO}_{2}$, heated at a temperature of $90^{\circ} \mathrm{C}$ for 2 hours, hydrolyzed and delignified to remove lignin and bleached, then separated from betha and gamma cellulose by dissolving it with $\mathrm{NaOH} 17.5 \%$. In this study, a preliminary treatment (pretreatment) with microwave heating was carried out before the fiber was hydrolyzed so that the hydrolysis process was more efficient without reducing the characteristics of the alpha cellulose produced. The research results showed that pretreatment with microwave heating can streamline the hydrolysis time from 2 hours to 1 hour, without reducing its characteristics, where the degree of fiber crystallinity (XRD) and the yield of alpha cellulose remain high. Microwave heating with 450 watts for 5 minutes (treatment A) is better than 300 watts of heating for 10 minutes (treatment B). From the results of the study, it can be concluded that the pretreatment with microwave heating can streamline the hydrolysis time of the fiber to obtain alpha cellulose and increase the yield of the produced alpha cellulose.
\end{abstract}

Keywords: Microwave, Preliminary treatment/pretreatment, Hydrolysis, $\alpha$-Cellulose, OPEFB, Mesocarp

\begin{abstract}
ABSTRAK
PENGARUH PERLAKUAN PENDAHULUAN PEMANASAN MICROWAVE TERHADAP EFISIENSI WAKTU HIDROLISIS DAN KARAKTERISTIK $\alpha$-SELULOSA DARI BIOMASSA LIMBAH KELAPA SAWIT. Penelitian ini dilatarbelakangi oleh kebutuhan berbagai industri terhadap alfa selulosa terutama untuk keperluan bahan baku nanokristallin selulosa, dari serat yang bersumber dari biomassa limbah paling potensial di Indonesia yaitu serat tandan kosong kelapa sawit (TKKS) dan serat mesocarp. Penelitian ini bertujuan untuk mengetahui pengaruh perlakuan pendahuluan (pretreatment) denganpemanasan microwave terhadap efisiensi waktu hidrolisis dan karakteristik alfa selulosa dari biomassa limbah kelapa sawit.Untuk menghasilkan alfa selulosa umumnya digunakan hidrolisis asam dengan metode multistage pulping process, dimana serat dilarutkan kedalam asam campuran $\mathrm{HNO}_{3} 3,5 \%$ dan $\mathrm{NaNO}_{2}$, dipanaskan pada suhu $90{ }^{\circ} \mathrm{C}$ selama
\end{abstract}


2 jam, dihidrolisis dan didelignifikasi untuk menghilangkan lignin lalu diputihkan (bleaching), setelah itu dipisahkan dari betha dan gamma selulosa dengan melarutkannya dengan $\mathrm{NaOH}$ 17,5\%. Dalam penelitian ini dilakukan perlakuan pendahuluan dengan pemanasan microwave sebelum serat dihidrolisis agar proses hidrolisis lebih efisien tanpa mengurangi karakteristik alfa selulosa yang dihasilkan. Hasil penelitian menunjukkan bahwa perlakuan pendahuluan dengan pemanasan microwave dapat mengefisienkan waktu hidrolisis dari 2 jam menjadi 1 jam, dengan tidak mengurangi karakteristiknya, dimana derajat kristalinitas serat (XRD) dan rendemen alfa selulosa tetap tinggi. Pemanasan microwave dengan daya 450 watt selama 5 menit (perlakuan A) lebih baik dari pada pemanasan dengan daya 300 watt selama 10 menit (perlakuan B). Dari hasil penelitian dapat disimpulkan bahwa perlakuan pendahuluan dengan pemanasan microwave dapat mengefisienkan waktu hidrolisis serat untuk memperoleh alfa selulosa dan meningkatkan rendemen alfa selulosa yang dihasilkan.

Kata kunci: Microwave, Perlakuan pendahuluan, Hidrolisis, $\alpha$-selulosa, TKKS, Mesocarp

\section{INTRODUCTION}

Alfa $(\alpha)$ cellulose is long-chain cellulose, with PD (polymerization degree) of 600 - 1500, insoluble in $17.5 \% \mathrm{NaOH}$ solution or strong base solution and used as an estimator and/or determinant of cellulose purity levels [1]. To obtain alpha cellulose, a multistage pulping process method is used. The lignocellulose material was dissolved into an acid mixture of $3.5 \% \mathrm{HNO}_{3}$ and $\mathrm{NaNO}_{2}$, heated at $90{ }^{\circ} \mathrm{C}$ for 2 hours, hydrolyzed and delignified to remove lignin and bleached, then separated from betha and gamma cellulose by dissolving with $\mathrm{NaOH} 17.5 \%$.

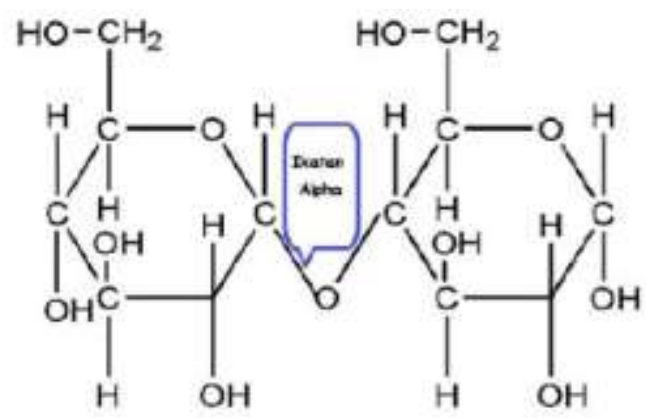

Figure 1. Structure of $\alpha$-Cellulose [1]

Alpha cellulose can be used in various purposes such as raw material for cellulose nanocrystalline, making propellants and raw materials for paper industry. Especially for cellulose nanocrystalline, cellulose with a high degree of crystallinity is preferred. The lignocellulose material is identified as the most promising source of natural cellulose to be used as raw material for alpha cellulose. In Indonesia, palm oil waste biomass is the most potential source of lignocellulose material because Indonesia is the largest producer of palm oil (CPO \& CPKO) in the world. The palm oil processing industry is a national priority industry to be developed with the consideration of the potential supply of abundant raw materials [2], so that in the future abundant waste will be produced as a by-product of production processes that need to be overcome. The intended waste is solid waste in the form of oil palm biomass, namely oil palm empty fruit bunch (OPEFB) and palm fruit fiber (mesocarp). OPEFB fibers are the most potential to be used as natural cellulose sources for alpha cellulose isolation because they have high cellulose content, as well as mesocarp fibers. The lignocellulose material from OPEFB fibers has a rigid structure because the cellulose crystalline microfibrils are associated with lignin and cellulose [3]. For this reason, a pretreatment is needed to separate it so that the hydrolysis and delignification processes can be carried out effectively and efficiently.

The pretreatment aims to make cellulose fibers more accessible in the process of acid hydrolysis by changing the structure of lignocellulose fibers. The main purpose is to remove lignin, disrupt the crystal structure of cellulose, and reduce the structure of disturbing biomass (recalcitrance) [4,5]. One prospective pretreatment method is to use microwaves.

Microwave is generally defined as electromagnetic waves which have frequencies between $300 \mathrm{MHz}$ to $300 \mathrm{GHz}$ [6]. Microwaves can induce heat to the molecular level through direct conversion of electromagnetic energy and help reduce energy consumption and reaction time compared to conventional heating, because microwaves can intensively transfer heat and improve reaction activities of raw materials [7]. Microwave irradiation has a high heating efficiency, so it can reduce the content of lignin and hemicellulose [8]. Unlike the case with conventional heating, the heat transferred by convection, conduction and radiation from the surface to the inside of the material, microwave heating is faster and more effective in breaking down the complex lignin structure [6] [9]. Microwave systems spread heat evenly and are very effective, easy to operate, very selective and easy to start and stop at any time $[9,10]$.

Research using microwave radiation as a pretreatment was carried out by several researchers previously, such as alkali pretreatment with the help of microwave and banana enzymatic hydrolysis [5], microwave-assisted alkali pretreatment for sugar production from banana peel waste [11], microwaveassisted acid pretreatment in oil palm empty fruit bunches to increase sugar production for fermentation [3], microwave-assisted acid pretreatment to see the characteristics and behavior of pyrolysis of bamboo 
sawdust [4], sugar production from bagasse with microwave-assisted alkaline acid pretreatment for sugar production from bagasse [8], microwave-assisted dilute acid pretreatment from a variety of different agricultural resources for fermented sugar production [12], microwave-assisted alkaline pretreatment on rice straw to improve enzymatic digestibility [7]. However, no research discussion has been found that links between heating by microwave as a pretreatment and the effectiveness of acid hydrolysis process on fiber to produce alpha cellulose.

The purpose of this study was to find out the effect of the pretreatment of microwave heating on the efficiency of hydrolysis time and the characteristics of alpha cellulose of biomass palm oil waste.

\section{EXPERIMENT METHOD}

\section{Materials and Equipment}

The raw materials used in this study were oil palm empty fruit bunches (OPEFB) and palm oil fiber (mesocarp) obtained from the palm oil processing plant PTPN VII Lampung. Some chemicals (absolute) are $\mathrm{HNO}_{3}$ $\mathrm{NaNO}_{2}, \mathrm{NaOH}, \mathrm{Na}_{2} \mathrm{SO}_{3}, \mathrm{NaOCl}, \mathrm{H}_{2} \mathrm{O}_{2}$, and $\mathrm{H}_{2} \mathrm{SO}_{4}$. While the main equipment used was the hammer mill, 40 mesh sieve, microwave, and hot plate stirrer. Test equipment needed includes X-Ray Diffraction (XRD), fourier transform infrared (FTIR), and scanning electron microscopy (SEM).

\section{Pretreatment of OPEFB and Mesocarp Fibers using Microwave Heating}

OPEFB and mesocarp fibers were each weighed as much as $75 \mathrm{~g}$, then given a pretreatment using microwave Samsung MS28J5255UB with an operating frequency of $2450 \mathrm{MHz}$ and a power output of $1000 \mathrm{~W}$. The pretreatment was carried out in 2 treatments; treatment A (pretreatment with microwave heating of 450 $\mathrm{W}$ for 5 minutes) and $\mathrm{B}$ (preliminary treatment with microwave heating of $300 \mathrm{~W}$ for 10 minutes). The combination of power and time in treatments A and B was chosen based on the best treatment tried on the sample, where time was adjusted to power. If time is made greater than the power given to treatments A and B, the sample will be burnt.

After the pretreatment of fiber, an analysis of the degree of crystallinity (XRD) was conducted, functional groups (FTIR) and surface morphology (SEM) were determined. Then, the fiber was isolated from its alpha cellulose.

\section{Degree of Crystallinity (XRD)}

For the measurement of the degree of crystallinity, XRD (MAXima X XRD-7000 Shimadzu, Japan) was used with angles ranging from $2 \theta=0^{\circ}-40^{\circ}$ with step $2 \theta=0.02^{\circ}$. The analysis was carried out using $\mathrm{Cu} \mathrm{K \alpha}$ irradiation with a voltage of $40 \mathrm{kV}$, current of $30 \mathrm{~mA}$ and a wavelength of $1,54 \AA$.

\section{Functional groups (FTIR)}

The functional groups contained in the fiber and alpha cellulose of OPEFB and mesocarp fibers were analyzed using Perkin Elmer Frontier FTIR spectrometer with wave numbers of $400-4000 \mathrm{~cm}^{-1}$.

\section{Water level (TAPPI T 257 om-85) [13]}

About $2 \pm 0.001 \mathrm{~g}$ (A) samples were weighed in weighing bottles, then dried for 2 hours in an oven at a temperature of $103 \pm 2{ }^{\circ} \mathrm{C}$, cooled in a desiccator and weighed. The sample was again dried for 1 hour, cooled and weighed. This method was repeated until a constant weight (B) is reached, that is until the weighing does not change more than $0.002 \mathrm{~g}$. The water content of the sample was calculated in percent close to $0.1 \%$, is expressed as the water weight to the weight of the dry sample.

$$
\text { Water Level }(\%)=\frac{A-B}{B} \times 100
$$

\section{Surface Morphology (SEM)}

Surface morphology of fiber and alpha cellulolose of OPEFB and mesocarp fibers was observed using Hitachi SEM Model:S-3400 Ltd Japan. Specimens were prepared by placing samples of fiber and alpha cellulose of OPEFB and mesocarp fibers on double sided carbons in high vacuum mode.

\section{Isolation of Alpha Cellulose and Characterization}

Isolation of Alpha Cellulose refers to the modified method of Sumaiyah et al. [14]. 75 grams each of OPEFB and mesocarp fibers were put into a beaker glass, then added $1 \mathrm{~L}$ mixture of $3.5 \% \mathrm{HNO}_{3}$ and $10 \mathrm{mg} \mathrm{NaNO}$, heated on a hot plate at $90^{\circ} \mathrm{C}$ for 2 hours. After that, they were filtered and the pulp was washed until the filtrate was neutral, then dissolved with $750 \mathrm{ml}$ of solution containing $2 \% \mathrm{NaOH}$ and $2 \% \mathrm{Na}_{2} \mathrm{SO}_{3}$ at $50^{\circ} \mathrm{C}$ for 1 hour. Then filtered and washed until neutral. Next, bleaching was carried out with $250 \mathrm{~mL}$ of $1.75 \% \mathrm{NaOCl}$ solution at a boiling temperature for 0.5 hours. Then filtered and and the pupp was washed until the filtrate $\mathrm{pH}$ was neutral. After that, alpha cellulose was purified with $500 \mathrm{~mL}$ of $17.5 \% \mathrm{NaOH}$ solution at $80{ }^{\circ} \mathrm{C}$ for 0.5 hours. Then filtered, washed until the filtrate was neutral. Continue bleaching with $10 \% \mathrm{H}_{2} \mathrm{O}_{2}$ at $60{ }^{\circ} \mathrm{C}$ for 5 minutes, then drying it in an oven at $70{ }^{\circ} \mathrm{C}$ for 1 hour. It was stored in the desiccator. The alpha cellulose obtained was observed in the form of 
yield, and degree of crystallinity (XRD). The same process was carried out on treated samples but by shortening the acid hydrolysis time to just 1 hour.

\section{Yield}

The yield was calculated based on the comparison between the mass of the product with the initial mass (per dry weight or per wet weight), i.e. the alpha cellulose dry weight obtained compared to the dry weight of the initial sample mass.

$$
\text { Yield }(\%)=\frac{\text { alpha cellulose weight }}{\text { initial fiber weight }} \times 100
$$

\section{RESULTS AND DISCUSSION}

\section{The Effect of Pretreatment by Microwave Heating on the Efficiency of Hydrolisis Time}

\section{Degree of Crystallinity (XRD)}

The results of the degree of crystallinity (XRD) analysis of the sample after applying the pretreatment with microwave heating are presented in Table 1. While the diffractogram is shown in Figure 2.

Table 1. Degree of Crystallinity of OPEFB and Mesocarp Fibers.

\begin{tabular}{llll}
\hline \multirow{2}{*}{ Fiber Source } & \multicolumn{3}{c}{ Degree of Crystallinity (\%) } \\
\cline { 2 - 4 } & Control & Treatment A & Treatment B \\
\hline OPEFB & 18.78 & 22.17 & 21.07 \\
Mesocarp & 16.34 & 17.19 & 16.62 \\
\hline
\end{tabular}

The degree of crystallinity of OPEFB fiber was higher than mesocarp both in control and treatment. The degree of crystallinity of the fiber given a pretreatment by microwave heating was higher than without the pretreatment (control). However, the fiber crystallinity degree of treatment A (preliminary treatment with microwave heating of $450 \mathrm{~W}$ for 5 minutes) was higher than the fiber from treatment B (preliminary treatment with microwave heating of $300 \mathrm{~W}$ for 10 minutes). The high fiber crystallinity degree by pre-treatment of microwave heating compared to without a preliminary treatment can be explained. In biomass (OPEFB and mesocarp fibers), naturally lignin and hemicellulose are amorphous parts while cellulose is crystalline [7]. The increase in the crystallinity degree of fibers after pretreatment with microwave is possible due to removal of amorphous parts in the form of lignin and hemicellulose [11]. As a result of its removal from the crystalline part, the individual crystals will be released, so that the degree of crystallinity increases. This can be seen from the changes in cellulose structure that occurred in cellulose fibrils which were given pretreatment illustrated in the results of SEM analysis (Figure 3).

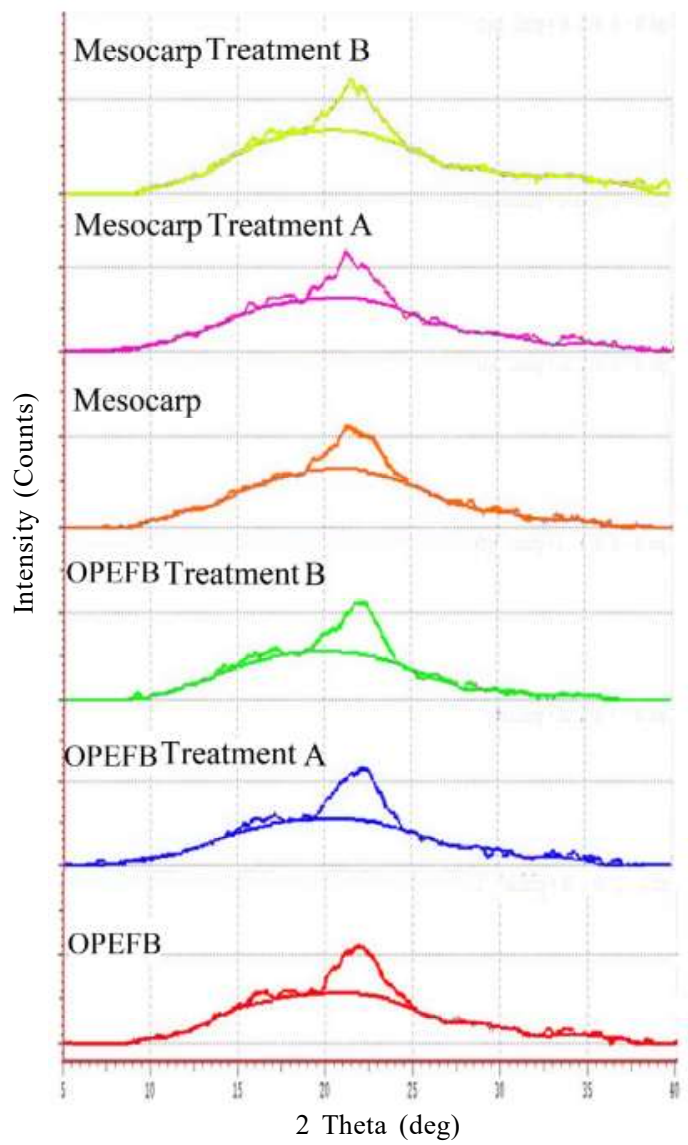

Figure 2. X Ray Diffractogram of OPEFB and Mesocarp Fibers.

Fiber given pretreatment with microwave heating at 450 watts for 5 minutes (treatment A) has a degree of crystallinity which tends to be higher than fiber which was given a pretreatment with microwave heating at 300 watts for 10 minutes (treatment B), be it on TKKS and mesocarp fibers. This illustrates that microwave irradiation with 450 watts for 5 minutes is more effective at removing amorphous parts of fiber and releasing individual crystals. In microwave irradiation, electromagnetic waves and energy are transferred directly into the material, compared to conventional heating where heat moves from the surface to the inner area. Microwaves uniformly change the structure of ultra cellulose in a short span of time without producing product waste [11]. With the greater power given to the material in the process of microwave radiation, the transfer of electromagnetic waves and energy will be faster into the material than the lower power, so the process of releasing the amorphous part takes place more effectively.

\section{Surface Morphology (SEM)}

The surface morphology of OPEFB and mesocarp fibers with and without treatment can be seen in Figure 3. 

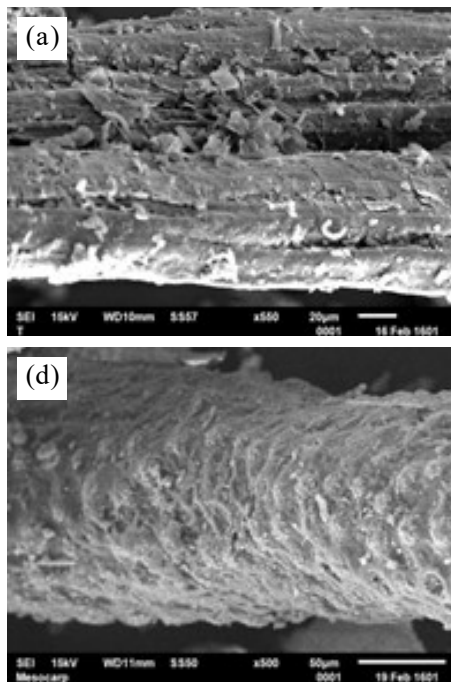
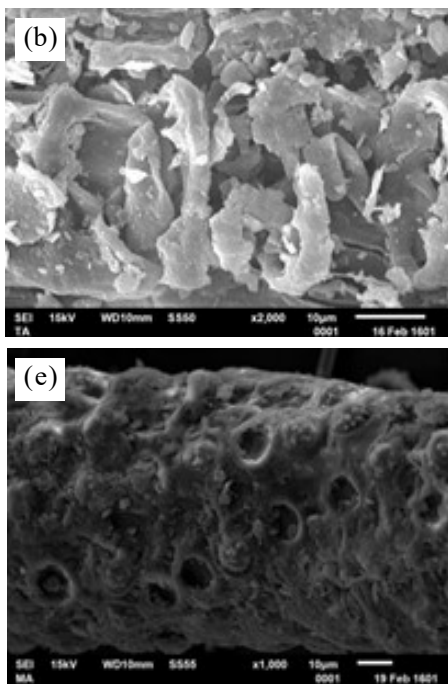
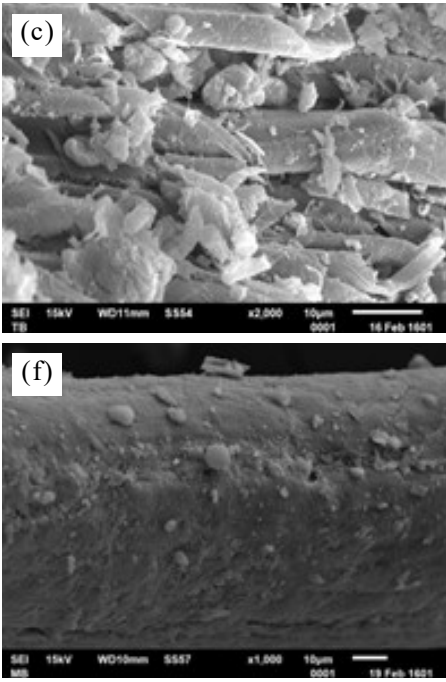

Figure 3. SEM Photos a. OPEFB b. Treatment-A OPEFB c. Treatment-B OPEFB d. Mesocarp e. Treatment-A Mesocarp f. Treatment-B Mesocarp.

The results of SEM analysis showed the pretreated structural morphology of the surface of OPEFB and mesocarp fibers given treatment $\mathrm{A}$ (pretreatment with microwave heating at 450 watts for 5 minutes), (Figure 3(b)) and treatment B (pretreatment with microwave heating at 300 watts for 10 minutes) (Figure 3(c)), the surface structure of cellulose cell walls looks softened, the surface becomes more brittle than untreated cellulose structures (Figure 3(a)). Whereas in mesocarp fibers by treatment A (Figure 3(f)), the surface of cellulose structure looks hollow, while with treatment B (Figure $3(\mathrm{~g})$ ) there are cracks on the surface of the cellulose structure.

Pretreatment with microwave heating can cause changes in the cell wall surface [11]. Microwave heating can damage fiber structures such as forming holes, cracking on the surface, and softening the structure. These changes are affected by lignin removal [3]. This finding is in line with the observation of morphological characteristics in microwave-treated betung bamboo [15].

\section{Functional Groups (FTIR)}

OPEFB and mesocarp fibers are composed of the main components including lignin, hemicellulose and cellulose. The three components are composed of alkanes, esters, aromatics and alcohol [16]. The results of functional group analysis (FTIR) of OPEFB and mesocarp fibers with and without treatment can be seen in Table 2 and Figure 4.

FTIR analysis was aimed to find out changes in functional groups after microwave heating. Strong and wide absorption is found in the absorption area of the range $3200-3600 \mathrm{~cm}^{-1}$ which indicates the presence

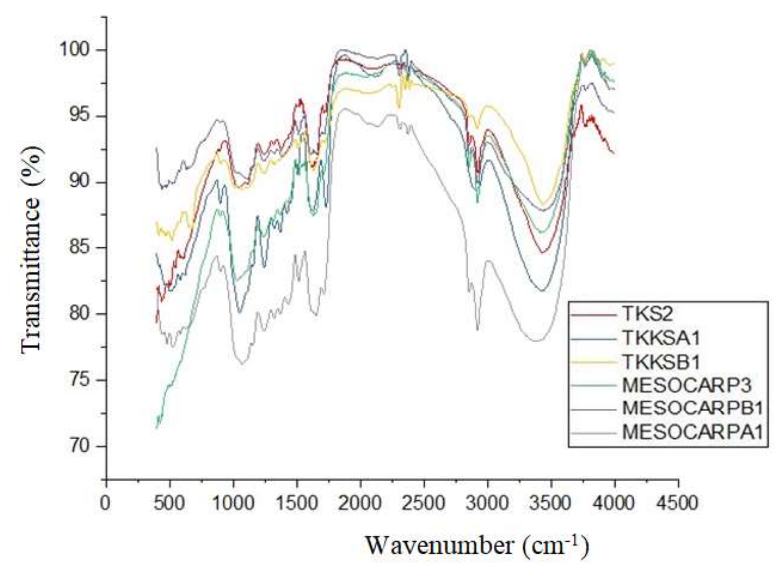

Figure 4. Spectra of FTIR, OPEFB (TKS2), TreatmentA OPEFB (OPEFB A1), Treatment-B OPEFB (OPEFB B1), Mesocarp (Mesocarp3), Treatment-A Mesocarp (Mesocarp A1) and Treatment-B Mesocarp (Mesocarp B1).

Table 2. Peak Position and Functional Group Marker of OPEFB and Mesocarp Fibers

\begin{tabular}{|c|c|c|c|c|c|c|c|c|c|c|}
\hline Treatment & $\begin{array}{l}\text { O-H }{ }^{[16]} \\
\text { Water } \\
\text { stretch } \\
\left(\mathrm{cm}^{-1}\right)\end{array}$ & $\begin{array}{l}\text { C-H }{ }^{[16]} \\
\text { Alkane } \\
\text { stretch } \\
\left(\mathrm{cm}^{-1}\right)\end{array}$ & $\begin{array}{c}-\mathrm{C} \Xi \mathrm{C}-^{[17]} \\
\text { Alkyne } \\
\text { stretch } \\
\left(\mathrm{cm}^{-1}\right)\end{array}$ & $\begin{array}{c}\mathrm{C}=\mathrm{O}^{[17]} \\
\text { Carbonyl } \\
\text { stretch } \\
\left(\mathrm{cm}^{-1}\right)\end{array}$ & $\begin{array}{l}\mathrm{C}=\mathrm{C}^{[17}[ \\
\text { Alkene } \\
\text { stretch } \\
\left(\mathrm{cm}^{-1}\right)\end{array}$ & $\begin{array}{c}\mathrm{C}=\mathrm{C}^{[17]} \\
\text { Aromatic } \\
\text { stretch } \\
\left(\mathrm{cm}^{-1}\right)\end{array}$ & $\begin{array}{l}-\mathrm{C}-\mathrm{H}^{[17]} \\
\text { Alkane } \\
\text { bending } \\
\left(\mathrm{cm}^{-1}\right)\end{array}$ & $\begin{array}{l}\text { C-N }{ }^{[17]} \\
\text { Amine } \\
\text { stretch } \\
\left(\mathrm{cm}^{-1}\right)\end{array}$ & $\begin{array}{l}\text { stretch } \\
\left(\mathrm{cm}^{-1}\right)\end{array}$ & $\begin{array}{l}\mathrm{C}-\mathrm{O}^{17]} \\
\text { Ester } \\
\text { stretch } \\
\left(\mathrm{cm}^{-1}\right)\end{array}$ \\
\hline OPEFB & 3425.58 & 2926.01 & - & 1722.43 & 1627.92 & 1440.00 & 1377.17 & 1246.02 & 1114.86 & 1043.49 \\
\hline OPEFB Treatment A & 3421.72 & 2906.73 & 2119.77 & 1732.08 & 1614.42 & 1423.47 & 1371.39 & 1244.09 & 1153.43 & 1049.28 \\
\hline OPEFB Treatment B & 3435.22 & 2918.30 & - & 1718.58 & 1633.71 & - & 1325.10 & 1242.16 & 1114.86 & 1018.41 \\
\hline Mesocarp & 3419.79 & 2924.09 & - & 1712.79 & 1625.99 & 1435.04 & 1373.32 & 1240.23 & 1105.21 & 1028.06 \\
\hline Mesocarp Treatment A & 3352.28 & 2924.09 & 2129.41 & 1714.72 & 1653.00 & 1435.04 & 1371.39 & 1240.23 & 1153.43 & 1070.49 \\
\hline Mesocarp Treatment B & 3439.08 & 2924.09 & - & 1714.72 & 1654.92 & - & 1388.75 & 1242.16 & 1109.07 & 1028.06 \\
\hline
\end{tabular}


of a $-\mathrm{OH}$ functional group. In Figure 4 the presence of peaks is shown at wave numbers $3425.58 \mathrm{~cm}^{-1}$, $3421.72 \mathrm{~cm}^{-1}, 3435.22 \mathrm{~cm}^{-1}, 3419.79 \mathrm{~cm}^{-1}, 3352.28 \mathrm{~cm}^{-1}$, and $3439.08 \mathrm{~cm}^{-1}$. $-\mathrm{OH}$ functional group is found in all samples. This means that the sample after pretreatment with microwave heating still contains water, although the levels are different. This explanation is supported by data on the water content of samples that experience shrinkage after the pretreatment on the sample. This shrinkage occurs both for OPEFB and mesocarp samples (Table 3).

Table 3. Water content of OPEFB and Mesocarp

\begin{tabular}{lc}
\hline \multicolumn{1}{c}{ Treatment } & Water Content (\%) \\
\hline OPEFB & 6.94 \\
OPEFB Treatment A & 4.96 \\
OPEFB Treatment B & 4.72 \\
Mesocarp & 8.43 \\
Mesocarp Treatment A & 6.69 \\
Mesocarp Treatment B & 6.16 \\
\hline
\end{tabular}

Besides the $-\mathrm{OH}$ functional groups, $\mathrm{C}-\mathrm{H}$ (alkane) and $\mathrm{C}-\mathrm{O}$ (ester) groups are also found in all samples. However, $\mathrm{C}=\mathrm{C}$ (aromatic) group is only found in OPEFB sample, Treatment-A OPEFB, mesocarp and treatmentA mesocarp. While in the saple of treatment-B and OPEFB and treatment-B mesocarp, there is no peak that indicates the aromatic component. This is assumed to be due to the microwave heating treatment for 10 minutes of 300 watts which affects the presence of functional groups of materials.

Meanwhile there is the emergence of a new functional group after the sample is treated by microwave heating for 5 minutes with 450 watts (treatment A) both at TKKS and mesocarp. The functional group is alkina with absorption bands of $2119.77 \mathrm{~cm}^{-1}$ and $2129.41 \mathrm{~cm}^{-1}$.

Cellulose is composed of 3 main functional groups, namely $\mathrm{C}-\mathrm{O}, \mathrm{O}-\mathrm{H}$ and $\mathrm{C}-\mathrm{H}$ [18]. The three groups are found in all samples despite the microwave heating given to the samples.

Some beneficial aspects of microwave irradiation of berlignocellulose materials are enrich the degradation of lignin and hemicellulose, and provide more potential exposed cellulose [7]. A large amount of damage to the fiber structure will significantly increase the reactive surface area and improve the hydrolysis reaction [3]. In the process of acid hydrolysis, the microwave heating pretreatment carried out on the fiber before hydrolysed can increase the surface of reactive fiber which will react with acid.

From the results of the study, pretreatment with microwave heating can streamline the hydrolysis time by half compared with no preliminary treatment i.e. from the duration of 2 hours to 1 hour, without reducing the fiber characteristics where the crystallinity degree (XRD) of fiber remains high, and the fiber surface is more porous
(SEM). The hydrolysis time efficiency is caused by an increase in porosity in the material due to fiber damage caused by microwave radiation. As a result, the hydrolysis process takes place more quickly and effectively.

\section{The Effect of Pretreatment with Microwave Heating to the Characteristics of Alpha $(\alpha)$ Cellulose}

\section{Degree of Crystallinity (XRD)}

The degree of crystallinity of alpha cellulose in the control, treatment A and treatment B was higher than the raw material both in alpha cellulose of OPEFB

Table 4. Degree of Crystallinity of Alpha Cellulose of OPEFB and Mesocarp

\begin{tabular}{lccc} 
Source of Alpha & \multicolumn{3}{c}{ Degree of Crystallinity (\%) } \\
\cline { 2 - 4 } \multicolumn{1}{c}{ Cellulose } & Control & Treatment A & Treatment B \\
\hline OPEFB & 31.17 & 29.14 & 23.21 \\
OPEFB Treatment A & 25.97 & 23.82 & 22.03 \\
\hline
\end{tabular}

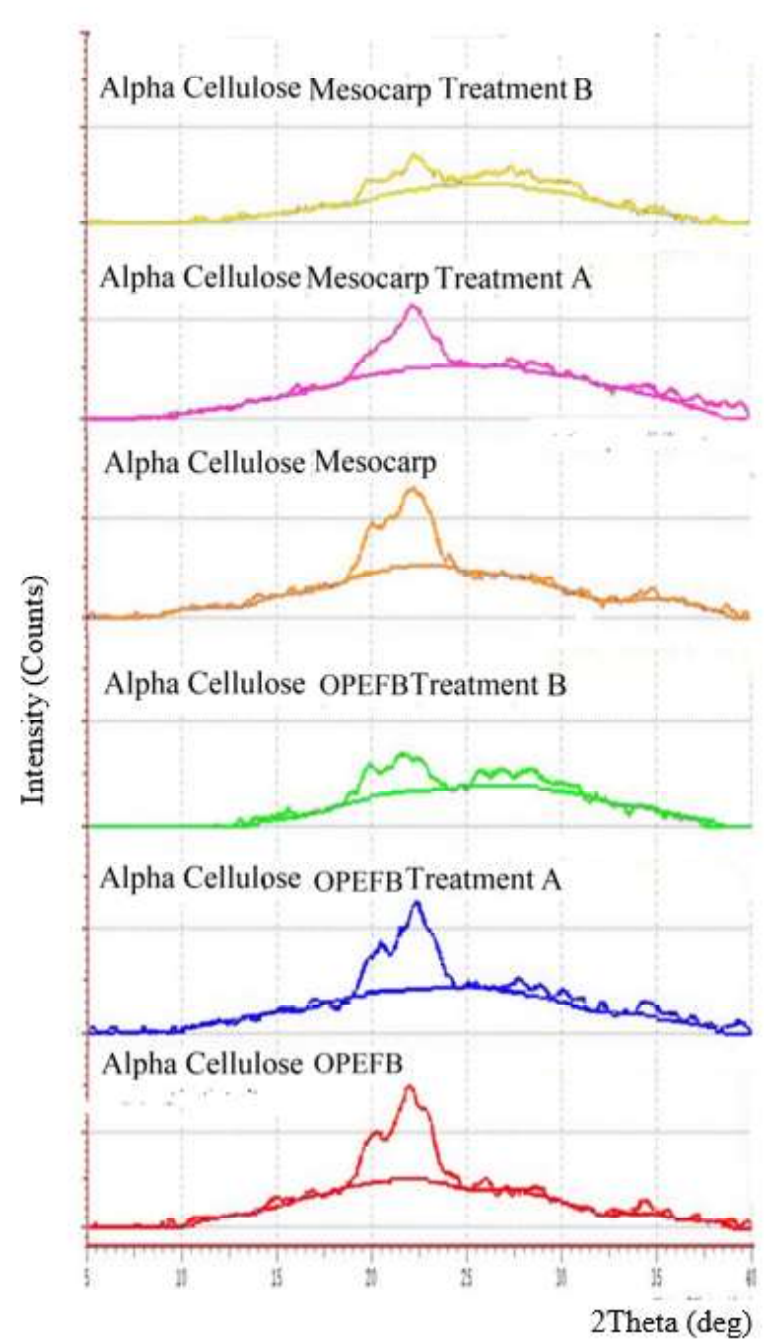

Figure 5. X Ray Diffractogram of Alpha Cellulose of OPEFB and Mesocarp 
and of mesocarp. The high degree of crystallinity of alpha cellulose compared to its original fiber (Table 4, Figure 5) can be explained as follows. When the isolation of alpha cellulose takes place, the fibers undergo removal of amorphous parts in the form of lignin and hemicellulose during the acid hydrolysis process. As a result, there is a release of amorphous parts of the crystalline part, thus releasing individual crystals, consequently the degree of crystallinity increases [19, 20].

Alpha cellulose of the fiber given treatment $\mathrm{A}$ (pretreatment with microwave heating at 450 watts for 5 minutes), as well as treatment-A raw material, the degree of crystallinity was also higher compared to that of fiber given treatment B (pretreatment with microwave at 300 watts for 10 minutes). The explanation of this phenomenon is explained above in point 1 .

\section{Yield}

The results of calculating the yield of OPEFB and mesocarp fibers given pretreatment with microwave heating can be seen in Table 5 .

Table 5. Yield of Alpha Cellulose of OPEFB and Mesocarp

\begin{tabular}{lccc}
\hline \multirow{2}{*}{$\begin{array}{c}\text { Source of Alpha } \\
\text { Cellulose }\end{array}$} & \multicolumn{3}{c}{ Yield of Alpha Celluloce (\%) } \\
\cline { 2 - 4 } OPEFB & 31.17 & 29.14 & 23.21 \\
\hline 1 & 31.60 & 34.98 & 68.04 \\
2 & 33.35 & 35.69 & 77.41 \\
\hline Average & 32.48 & 35.34 & 72.72 \\
\hline Mesocarp & 25.97 & 23.82 & 22.03 \\
\hline 1 & 14.95 & 20.18 & 65.29 \\
2 & 17.07 & 16.70 & 50.57 \\
\hline Average & 16.01 & 18.44 & 57.93 \\
\hline
\end{tabular}

The yield of alpha cellulose fibers given microwave heating is higher than without one. This is because the hydrolysis process takes place effectively as the material has been porous (SEM results) after pretreatment with microwave heating so that acidic chemicals react effectively without requiring longer time and do not damage the cellulose structure excessively so that the yield of alpha cellulose remains high. This is assumed to be caused by microwave heat waves that are selective and delivered to the material evenly so that the delignification process in the alpha cellulose isolation process takes place effectively as the material structure is open and a poreshaped hole is formed due to exposure to microwave heat waves.

If the results of the research data are observed, the degree of crystallinity of alpha cellulose is inversely proportional to the yield (Tables 4 and 5). The smaller the yield of alpha cellulose, the higher the degree of crystallinity. This is because alpha cellulose with the lowest yield being are all read as crystalline regions, causing the percentage portion of the crystalline area to increase.

The yield of alpha cellulose with treatment A (pretreatment with microwave heating of 450 watts for 5 minutes) was lower than that of treatment B (pretreatment with microwave heating of 300 watts for 10 minutes), i.e. $35.34 \%$ and $18.44 \%$ respectively as for OPEFB and mesocarp with treatment $A$ and $72.72 \%$ and $57.93 \%$ respectively for OPEFB and mesocarp with treatment $\mathrm{B}$. However, even though the yield of treatment-A alpha cellulose was lower than $\mathrm{B}$, the degree of crystallinity was relatively higher. That was $29.14 \%$ and $23.82 \%$ for alpha cellulose of OPEFB and mesocarp with treatment $A$, and $23.21 \%$ and $22.03 \%$ for alpha cellulose of OPEFB and mesocarp with treatment B. Alpha cellulose from treatment A remained better than treatment $\mathrm{B}$, because it was specifically used as raw material for cellulose nanokristallin, cellulose with a high degree of crystallinity is preferred.

\section{CONCLUSION}

From the results of the study, it can be concluded that microwave heating can streamline the hydrolysis time of fiber to obtain alpha cellulose of fibers and increase the yield of the produced alpha cellulose.

\section{ACKNOWLEDGEMENT}

The author would like to thank Kemenristek Dikti for funding the research through the 2017 Doctoral Dissertation Grant in accordance with the research contract Number: 059/SP2H/LT/DRPM/IV/2017

\section{REFERENCES}

[1]. Nuringtyas and Rini T. Carbohydrat. Gajah Mada University Press, 2010, Yogyakarta.

[2]. N. Larasati, S. Chasanah, S. Machmudah, and S. Winardi. "Economic Analysis Study of CPO Plant(Crude Palm Oil) and PKO (Palm Kernel Oil) From Oil Palm Fruits."ITS Engineering Journal, Vol. 5, No. 2, pp. 212-215. 2016.

[3]. W. Fatriasari, SH. Anita and L. Risanto. "Microwave Assisted Acid Pretreatment of Oil Palm Empty Fruit Bunches (EFB) to Enhance Its Fermentable Sugar Production". Waste and Biomass Valorization, vol. 8, pp 379-391, March. 2017.

[4]. Y. Wang, D. Duan,Y. Liu, R. Ruan, G. Fu, L. Dai,Y. Zhou, Z. Yu, Q. Wu, and Z. Zeng. "Properties and Pyrolysis Behavior of Moso Bamboo Sawdust after Microwave-assisted Acid Pretreatment." .Journal of Analytical and Applied Pyrolysis, Dec. 2017.

[5]. S. Chittibabu, MK. Saseetharan, MR. Kalaivani and MP. Rajesh."Optimization of Microwave-assisted Alkali Pretreatment and Enzymatic Hydrolysis of Banana Pseudostem". Energy Sources Part A 
Recovery Utilization and Environmental Effects, vol. 36, pp 2691-2698, Dec. 2014.

[6]. Z. Zhu, CA. Rezende, R. Simister, SJ.McQueenMason, DJ.Macquarrie, I. Polikarpov and LD. Gomez. "Efficient Sugar Production from Sugarcane Bagasse by Microwave Assisted Acid and Alkali Pretreatment". Biomass and Bioenergy, vol. 93, pp 269-278, Oct. 2016.

[7] Z. Lu, L. Fan, H. Zheng, Q. Lu, Y. Liao, and B. Huang. "Preparation, Characterization and Optimization of Nanocellulose Whiskers by Simultaneously Ultrasonic Wave and Microwave Assisted". Bioresource Technology, vol. 146, pp 82-88, Oct. 2013.

[8]. R. Singh, S. Tiwari, M. Srivastava and A. Shukla. "Microwave Assisted Alkali Pretreatment of Rice Straw for Enhancing Enzymatic Digestibility". Journal of Energy, pp 1-7. 2014.

[9]. X. Kan, J. Zhang, YW. Tong and CH. Wang. “Overall Evaluation of Microwave-assisted Alkali Pretreatment for Enhancement of Biomethane Production from Brewers' Spent Grain”. Energy Conversion and Management, vol. 158, pp 315326, Feb. 2018.

[10]. H. Peng, H. Chen, Y. Qu, H. Li and J. Xu."Bioconversion of Different Sizes of Microcrystalline Cellulose Pretreated by Microwave Irradiation with/without NaOH".Applied Energy, vol. 117, pp 142-148, March. 2014.

[11]. G. Tiwari, A. Sharma, A. Kumar and S. Sharma. "Assessment of Microwave-assisted Alkali Pretreatment for The Production of Sugars from Banana fruit Peel Waste". Biofuels, pp 1-8, March. 2018.

[12] M. Germec, F. Damirel, N. Tas, A. Ozcan, C. Yilmazer, Z. Onuk and I. Turhan. "Microwave-assisted Dilute Acid Pretreatment of Different Agricultural Bioresources for Fermentable Sugar Production". Cellulose.July. 2017.

[13] [TAPPI] The Technical Association of The Pulp and Paper Industry. TAPPI Test Methods. Atlanta, TAPPI Press, 1996.
[14] Sumaiyah, B. Wirjosentono, Karsono, MP. Nasution and S. Gea. "Preparation and Characterization of Nanocrystalline Cellulose from Sugar Palm Bunch (Arenga pinnata (Wurmb) Merr.)"International Journal of PharmTech Research. vol. 6, No. 2, pp 814-820. 2014.

[15]. W. Fatriasari, W. Syafii, N. Wistara, K. Syamsu and B. Prasetya." Lignin and Cellulose Changes of Betung Bamboo (Dendrocalamusasper) Pretreated Microwave Heating". International Journal on Advanced Science Engineering Information Technology.vol.6, no. 2.Pp 186-195. 2016.

[16]. A. Gian A, M. Farid and H. Ardhyananta. "Cellulose Isolation from Oil Palm Empty Fruit Bunches for Nanofiller Sound Absorption Composites: FTIRAnalysis," ITS Technical Journal, vol. 6, No. 2. 2017.

[17] R.M. Silverstein, F.X. Webster and D.J. Kiemle. "Infrared Spectrometry," in Spectrometric Identification of Organic Compound, $7^{\text {th }}$ ed., John Wiley \& Sons, Inc. United States of America, 2005, pp. $80-108$

[18]. D. Tristantini, D.P. Dewanti and C. Sandra. "Isolation and Characterization of á-Cellulose from Blank Bunches of Palm Oil Dry Jackfruit Leaves with Alkaline Process $\mathrm{NaOH}$ Continued with Bleaching Process $\mathrm{H}_{2} \mathrm{O}_{2}$," in Proc of the $3^{\text {rd }}$ International Symposium on Applied Chemistry, 2017.

[19]. A. ZuliahaniA, A.S.N Hanani, R.N. Nadhirah and A. Hazirah. "Isolation and Characterization of Microcrystalline Cellulose (MCC) from Rice Husk (RH) and Kenaf : a Comparison Study". Solid State Science and Technology, vol. 25, No. 2 pp 96-102. 2017.

[20]. M.S.A. Safinas, A.A. Bahar and H. Ismail. "Properties of Kenaf Bast Powder Filled High Density Polyethylene/Ethylene Propylene Diene Monomer Composites". BioResources, vol. 8 (2), pp 2386-2397.2013. 